\title{
Residue and risk of ochratoxin $A$ in human plasma and beverages in Japan
}

\author{
Yoshio UENO* \\ 上野 芳夫：オクラトキシン A のヒト血清および飲料残留と危険度評価
}

\begin{abstract}
Employing a competitive ELISA (cELISA) based on monoclonal antibody (MAb) and an immunoaffinity-column (IAC)-linked HPLC-fluorometry, ochratoxin A (OTA) levels in the plasma of 184 healthy volunteers (130 males, 54 females) and the beverages including wine, beer, coffee, grape juice, spirits and soy-sauce (138 samples in total) were surveyed in Tokyo. It was found that $85 \%$ of the total human plasma sampled in 1992, 1994, 1995 and 1996 were positive for OTA except $38 \%$ in 1994, and an average value in the positives was estimated to $68 \mathrm{pg} / \mathrm{ml}$. This suggests that the population in Tokyo is exposed to OTA at high frequency, though the level in plasma is far less than that reported in Europe and Canada. Alcoholic drinks such red wine and beer, coffee products and soy-sauce were positive for OTA. A partial contribution of these alcoholic drinks, coffee and soy-sauce is suspected as the source of the OTA observed in the human plasma.
\end{abstract}

\section{Introduction}

Ochratoxin A (OTA) is a nephrotoxic mycotoxin of several fungal species belonging to the genera Aspergillus (e.g. A. alutaceus formerly known as $A$. ochraceus) and Penicillium (e.g. $P$. verrucosum $)^{1)}$. Its association with porcine endemic nephropathy ${ }^{2)}$ and Balkan endemic nephropathy ${ }^{3)}$ was pointed out. After findings the carcinogenic potential in rodents ${ }^{4,5)}$, residues in the plasma and edible tissues of swine ${ }^{2)}$, covalent binding to DNA of the cells of target tissues ${ }^{6}$ and immunosuppressive effect ${ }^{7)}$ of this mycotoxin, the relationship between its natural occurrence in foodstuffs and health hazards became a great concern in food toxicology, as reviewed $^{8-11)}$.

To determine OTA levels in foodsfuffs and biological fluids, HPLC-fluorometry is widely employed along with immunoassay ${ }^{12,13)}$. We have developed a sensitive ELISA based on monoclonal antibody ${ }^{14)}$ (MAb). By using this method, we have demonstrated that the residue of OTA in the plasma in domestic swine occurs at high frequency, though the level of OTA was far less than that reported in Denmark and other countries ${ }^{15,16)}$.

* Department of Toxicology and Microbial Chemistry, Faculty of Pharmaceutical Sciences, Science University of Tokyo, Ichigaya, Tokyo 162, Japan

* 東京理科大学薬学部毒性学・微生物化学教室（广162 東京都新宿区市ヶ谷船河原町 12)

* To whom all reprint requests and correspondence should be addressed.

Abbreviations: OTA, ochratoxin A ; ELISA, enzyme-linked immunosorbent assay ; HPLC, high performance liquid chromatography ; IAC, immunoaffinity column; MAb, monoclonal antibody ; PBS, phosphate buffered saline 
The presence of OTA in human plasma and its transmission to mother milk has been reported in several countries ${ }^{17-19}$. In this paper, the occurrence of OTA in the plasma of Japanese subjects was surveyed for 4-years by using sensitive ELISA and immunoaffinity column (IAC)-linked HPLC-fluorometry. The results showed that, among 184 cases, OTA was positive in 156 cases (85\%) with a mean value of $68 \mathrm{pg} / \mathrm{ml}$ in the positives, ranging from $4 \mathrm{pg} / \mathrm{ml}$ to $278 \mathrm{pg} /$ $\mathrm{ml}$.

In order to clarify the source of plasma OTA, several kinds of alcoholic drinks, coffee products and fermented products were analyzed by IAC-linked HPLC, and their partial contribution to plasma OTA was demonstrated. Some of the present data were reported elsewhere ${ }^{20-21)}$.

\section{Materials and Methods}

\section{Ochratoxin A}

OTA was isolated from the culture filtrate of Asp. alutaceus. Standard solution of OTA in methanol was stocked in the dark at $-30^{\circ} \mathrm{C}$. Its concentration was adjusted by using a molecular absorbance of 6,400 at $333 \mathrm{~nm}$.

\section{Human plasma}

The blood samples were collected from healthy volunteers consisting of students and a small number of staff members in the University during 13-16 p.m. using heparinized injection syringes. The blood samples were centrifuged at $3,000 \mathrm{rpm}$ for $20 \mathrm{~min}$, and the plasma were inactivated by heating at $60^{\circ} \mathrm{C}$ for $30 \mathrm{~min}$, and stocked at $-30^{\circ} \mathrm{C}$ until analysis.

Alcoholics, coffee and soy-sauce

Freeze-dried coffee (instant, 12 samples), canned coffee (10), granular coffee (10), wine (54), grape-juice (12), canned beer (20), soy-sauce (5), sake (rice wine 5), veniga (5), awamori (2) and shochu (3) (Japanese spirits), 138 samples in total, were purchased from a range of retail outlets in Japan in 1996.

\section{ELISA and immunoaffinity column-linked HPLC}

The competitive ELISA (cELISA) adopted for plasma OTA in swine ${ }^{15)}$ was basically applied for the human plasma samples collected in 1992, 1994 and 1995, with the following detection limits ; $10 \mathrm{pg} / \mathrm{ml}$ for 1992, $4 \mathrm{pg} / \mathrm{ml}$ for 1994 and $20 \mathrm{pg} / \mathrm{ml}$ for 1995 .

As for the plasma sampled in 1996, IAC-linked chromatography, developed for OTA analysis in coffee products ${ }^{22,23)}$ was slightly modified. The affinity gel $(0.2 \mathrm{ml})$ was packed in a minicolumn (Muromack Column, Muromachi Chemical Ind., Ltd., Tokyo), and equilibrated by passing $10 \mathrm{ml}$ of PBS at a flow rate of $20-40$ drops $/ \mathrm{min}$. Plasma samples $(2 \mathrm{ml})$ was mixed with $2 \mathrm{ml}$ of acetonitrile, voltexed for $1 \mathrm{~min}$, and centrifuged at 3,000 rpm for $20 \mathrm{~min}$. Three $\mathrm{ml}$ of the supernatant was mixed with $7 \mathrm{ml}$ of PBS to set the final concentration of acetonitrile to $15 \%$, and the whole $10 \mathrm{ml}$ was charged to the IAC. After washing the column with $10 \mathrm{ml}$ of PBS, OTA was eluted with $2 \mathrm{ml}$ of methanol. The solvent was evaporated under nitrogen gas, and the residue was dissolved in $0.1 \mathrm{ml}$ of acetonitrile-water $(1 / 1 \mathrm{v} / \mathrm{v})$ for HPLC analysis.

HPLC-fluorometry was carried out with Wakosil II 5C18 AR column (Wako Pure Chem. Ltd., Osaka), equipped with a HPLC pump (LC-10AD), column oven (CTO-6A), fluorometry detector (RF-550A) and integrator (C-R3A) (Shimadzu, Osaka). The development solvent system was 
$0.1 \%(\mathrm{w} / \mathrm{v})$ phosphoric acid-acetonitrile $(45: 55 \mathrm{v} / \mathrm{v})$ with a flow rate of $1.0 \mathrm{ml} / \mathrm{min}$, and OTA was detected at $330 \mathrm{~nm}$ (excitation) and $450 \mathrm{~nm}$ (emission). An average recovery of OTA from the plasma spiked with $50-100 \mathrm{pg} / \mathrm{ml}$ of OTA was $78.7 \%$, with a detection limit of $10 \mathrm{pg} / \mathrm{ml}$.

As for beverages, the procedure for coffee products ${ }^{22)}$ was essentially adopted, as briefly follows. Powdered coffee $(0.5 \mathrm{~g})$ was dissolved in $8 \mathrm{ml}$ of $1 \% \mathrm{Na}_{2} \mathrm{CO}_{3}$ solution, sonicated for 15 min, adjusted to $10 \mathrm{ml}$ with the above solution, filtered over a GF-prefilter (Minisarta GF, Sarcorius AG, Gottingen), and diluted with the same volume of phosphate buffered saline (PBS). The diluent $(10 \mathrm{ml})$ was charged over the IAC, and after washing the column with $10 \mathrm{ml}$ of PBS, OTA was eluted with $2 \mathrm{ml}$ of methanol. After an evaporation of the solvent, the residue was dissolved in $0.1 \mathrm{ml}$ of acetonitrile-water $(1: 1)$. Canned coffee $(5 \mathrm{ml})$ was filtrated, and directly applied for IAC. The concentrations of OTA in granular and instant coffees were expressed as $\mathrm{pg} / \mathrm{ml}$, based on $20 \mathrm{~g} / 140 \mathrm{ml}$ for drinking. Wine and beer $(5 \mathrm{ml})$ previously degassed were mixed with $1 \mathrm{ml}$ of $2.5 \% \mathrm{Na}_{2} \mathrm{CO}_{3}-1.5 \% \mathrm{NaCl}$ solution, charged to the IAC, and after washing the column sequentially with $10 \mathrm{ml}$ of $0.5 \% \mathrm{Na}_{2} \mathrm{CO}_{3}-2.5 \% \mathrm{NaCl}$ solution and PBS, the OTA was eluted with $2 \mathrm{ml}$ of methanol. Recovery of OTA from beverages spiked with OTA was over $90 \%$ (coffee), $80 \%$ (wine) and $90 \%$ (beer), with the detection limits of $60 \mathrm{pg} / \mathrm{g}$ (regular and instant coffee) and $3 \mathrm{pg} / \mathrm{ml}$ (canned coffee, wine, beer and grape-juice).

\section{Confirmation of ochratoxin A}

OTA in selected samples of human plasma and beverages positive for the above cELISA and IAC-HPLC was confirmed by methylation of OTA-positive fraction.

\section{Results and Discussion}

\section{Ochratoxin $\mathbf{A}$ in human plasma}

As summarized in Table 1, cELISA analysis showed that 93, 38 and 93\% of the plasma sampled in 1992, 1994 and 1995 were positive for OTA, and the means of the positives were estimated to 93,73 and $62 \mathrm{pg} / \mathrm{ml}$ respectively ${ }^{21)}$. No significant difference was observed between these three years. In addition, no statistical difference in the plasma OTA levels was observed between the male and female.

To avoid human hazard from chloroform which was used for liberation of OTA from the plasma proteins, various kinds of organic solvents were examined. Acetonitrile resulted in a high recovery of OTA from the OTA-spiked plasma. Thus, plasma samples shaked with acetonitrile were introduced to IAC, and followed by HPLC. The detection limit of OTA in the present IAC-HPLC analysis was $10 \mathrm{pg} / \mathrm{ml}$, which was comparable to the above cELISA method.

Adopting this novel IAC-HPLC procedure, OTA levels in 56 human plasma samples taken in 1996 were surveyed $^{21)}$. As shown in Table 1, 55 cases (98\%) were positive for OTA, with a mean of $63 \mathrm{pg} / \mathrm{ml}$, which was similar to the level detected in 1992-1995. Neither a sex nor age difference between subpopulations aged over 30 and below 30 volunteers was observed in the plasma OTA levels.

The four year surveys during 1992-1996 demonstrated that $85 \%$ of all the plasma sampled from a human population in the Tokyo area were positive for OTA and the level in the positives was averaged to $68 \mathrm{pg} / \mathrm{ml}$ without marked variation. Since the serum OTA levels were not 
Table 1 Ochratoxin A levels in human plasma

\begin{tabular}{|c|c|c|c|c|c|c|}
\hline Year & Samples & Positives (\%) & \multicolumn{3}{|c|}{ OTA $(\mathrm{pg} / \mathrm{ml})$} & Methods* \\
\hline 1992 & & & mean** & $\min$ & $\max$ & \\
\hline Total & 24 & $23(96)$ & 93 & 16 & 278 & cELISA \\
\hline male & 18 & $18(100)$ & 95 & 16 & 278 & \\
\hline $\begin{array}{l}\text { female } \\
1994\end{array}$ & 6 & $5(83)$ & 86 & 18 & 127 & \\
\hline Total & 34 & $14(38)$ & 73 & 4 & 263 & cELISA \\
\hline male & 25 & $11(44)$ & 83 & 4 & 263 & \\
\hline $\begin{array}{l}\text { female } \\
1995\end{array}$ & 9 & $2(22)$ & 18 & 7 & 30 & \\
\hline Total & 69 & $64(93)$ & 62 & 24 & 130 & cELISA \\
\hline male & 46 & $44(96)$ & 61 & 21 & 120 & \\
\hline $\begin{array}{l}\text { female } \\
1996\end{array}$ & 23 & $20(87)$ & 63 & 22 & 130 & \\
\hline total & 57 & $56(98)$ & 62 & 19 & 151 & IAC-HPLC \\
\hline male & 41 & $41(100)$ & 59 & 19 & 115 & \\
\hline $\begin{array}{l}\text { female } \\
\text { Sum }\end{array}$ & 16 & $15(94)$ & 75 & 23 & 151 & \\
\hline Total & 184 & $156(85)$ & 68 & 4 & 278 & \\
\hline male & 130 & $114(88)$ & 68 & 4 & 278 & \\
\hline female & 54 & $42(78)$ & 68 & 7 & 151 & \\
\hline
\end{tabular}

*Detection limits (pg/ml):10 for 1992, 4 for 199420 for 1995 and 10 for 1996.

*Mean of positives.

significantly different between the sexes and among the age-groups of the population examined, the source of the OTA is assumed to be common dietary foodstuffs. It was reported that the plasma OTA level in patients with urinary system tumors was reported to $20.3 \mathrm{ng} / \mathrm{ml}$, while that in the healthy families was $10.0 \mathrm{ng} / \mathrm{ml}$ in Bulgaria ${ }^{3)}$. The plasma OTA levels $(\mathrm{ng} / \mathrm{ml})$ in general population were reported to 1.5-2.3 in Denmark ${ }^{19)}, 0.17$ in Sweden ${ }^{24)}, 0.25$ and 1.3 in 1990 and 1991 respectively in Canada ${ }^{25)}$ and $0.23-0.42$ in Swiss $^{20}$. Although the whole plasma level averaged to $68 \mathrm{pg} / \mathrm{ml}$ in Tokyo (Table 1) is far less than those in Europe and Canada, the mean level in the dose ranging of $62-93 \mathrm{pg} / \mathrm{ml}$ for the 4 -year period is regarded as steady-state plasma level in Tokyo.

\section{Ochratoxin A levels in beverages}

To elucidate the possible source of OTA in the human subjects, IAC-HPLC method was adopted for the survey of OTA levels in various kinds of beverages and fermented products sampled in 1996, as summarized in Table 2.

Over $90 \%$ of canned and instant coffee were positive for OTA, while no OTA was detected in regular coffee. Based on the general concept that $20 \mathrm{~g}$ of regular and instant coffee were solved in $140 \mathrm{ml}$ of hot water for drink, the level of OTA in instant was about 50 times higher than canned coffee.

Among wine, all Italian and French red wine were positive for OTA, and its levels were several times higher than the others. HPLC analysis of a French red wine, which showed the 
Table 2 OTA in coffee products, alcoholics and grape-juice.

\begin{tabular}{lccc}
\hline \hline Samples & Positives/total & Mean $(\mathrm{pg} / \mathrm{ml})^{*}$ & Maximum(pg/ml)* \\
\hline Coffee & & & \\
canned & $9 / 10$ & 28 & 133 \\
instant & $12 / 12$ & 18 & 63 \\
regular & $0 / 10$ & - & \\
Red wine & & & \\
Italian & $5 / 5$ & 47 & 59 \\
French & $7 / 7$ & 77 & $245 \dagger$ \\
American & $0 / 3$ & - & \\
Australian & $0 / 3$ & - & \\
Chili & $0 / 2$ & - & \\
South Africa & $0 / 3$ & - & 15 \\
Japanese & $3 / 13$ & 4 & 6 \\
White wine & $1 / 5 \ddagger$ & 6 & 37 \\
Rose wine & $3 / 5 \neq$ & 24 & 4 \\
Blended $\varnothing$ & $2 / 7$ & 4 & 32 \\
Beer domestic & $10 / 14$ & 10 & \\
imported & $3 / 6 \S$ & 14 & 6 \\
Grape-juice & & & \\
red & $2 / 9$ & 6 & \\
white & $0 / 3$ & - & \\
\hline
\end{tabular}

${ }^{*}$ Expressed as $\mathrm{pg} / \mathrm{ml}$, based on $20 \mathrm{~g}$ coffee $/ 140 \mathrm{ml}$ for one cup of coffee drink. †Positive for OTA and OTC;

†One Germany; $\neq$ two French and one blended;§ Two American and one Australian.

$\varnothing$ Imported and domestic wine were blended.

Table 3 Ochratoxin A in fermented products in Japan

\begin{tabular}{lcc}
\hline \hline Samples & Positives/total(\%) & Mean(pg/ml)* \\
\hline Shochu & $0 / 3(0)$ & - \\
Awamori & $0 / 2(0)$ & - \\
Sake (rice wine) & $0 / 5(0)$ & - \\
Soy-sauce & $5 / 5(100)$ & $6.82 \dagger$ \\
Veniga & $0 / 5 \quad(0)$ & - \\
\hline
\end{tabular}

${ }^{*}$ Detection limit, $3 \mathrm{pg} / \mathrm{ml}$

$\dagger$ Maximum, $26.5 \mathrm{pg} / \mathrm{ml}$

highest level of OTA $(244 \mathrm{pg} / \mathrm{mL})$, revealed a presence of ochratoxin C. Domestic $(71 \%)$ and imported $(50 \%)$ canned beer were also positive for OTA, with the means of 10 and $14 \mathrm{pg} / \mathrm{ml}$ respectively. An interesting finding is that 2 out of 9 domestic red grape-juice samples were contaminated with OTA in $6 \mathrm{pg} / \mathrm{ml}$ level.

In previous paper ${ }^{27}$, the author reported that Asp. foedus, a starter for awamori (Japanese local spirit), possesses the producibility of OTA in culture. Further evidences showed that $A s p$. niger, taxonomically closed to Asp. foedus and widely employed for fermentation process for soy-sauce, miso (bean-pest) and other traditional foods in Asian countries, produces OTA ${ }^{28,29)}$. In 
this respect, the levels of OTA in Japanese wine (sake), awamori and shochu (Japanese local spirits), soy sauce and veniga were examined, as shown in Table 3. Among the samples tested, all 5 samples of soy-sauce were positive for OTA with an average of $6.8 \mathrm{pg} / \mathrm{ml}$. While, no OTA was detected in sake, spirits and veniga.

The present findings demonstrated that the Japanese population is exposed to OTA through various kinds of alcoholic drinks (wine and beer), coffee and fermented bean (soy-saurce).

\section{Risk for OTA}

Based on the findings that $1.3 \mathrm{ng} / \mathrm{ml}$ of plasma OTA in Canada corresponds to an intake of $1.7 \mathrm{ng} / \mathrm{kg}$ body weight per day ${ }^{30)}$ and the present 4-year plasma OTA level is averaged to $68 \mathrm{pg} /$ $\mathrm{ml}$ (Table 1), the intake of OTA is simply culculated to $0.08 \mathrm{ng} / \mathrm{kg}$ body weight/day or $0.56 \mathrm{ng} /$ kg body weight/week. Currently, the World Health Organization/Food and Agricultural Organization Joint Expert Committee on Food Additives (JECFA) proposed $100 \mathrm{ng} / \mathrm{kg}$ body weight as a Provisional Tolerable Weekly Intake (PTWI) for OTA ${ }^{31}$. In consideration of weak genotoxicity of OTA, this estimate seem to represent a virtually safe dose (VSD).

Based on the above findings, the author tried to calculate the possible maximum weekly OTA uptake as follows ; 1$)$ a daily intake of 5 cups $(600 \mathrm{ml})$ of instant coffee $(17 \mathrm{pg} / \mathrm{ml})$ gives 71 ng OTA ; 2$)$ a daily consumption of 0.21 of French red wine $(77 \mathrm{pg} / \mathrm{mL})$ gives $95 \mathrm{ng}$ OTA ; 3$)$ a daily intake of 0.51 of domestic beer $(10 \mathrm{pg} / \mathrm{ml})$ corresponds to $42 \mathrm{ng}$ OTA. If a person of $60 \mathrm{~kg}$ body weight consumed daily the above three items, the total weekly intake of OTA would be 298 ng OTA/person or $5 \mathrm{ng} \mathrm{OTA} / \mathrm{kg}$ body weight. It means that the calculated value corresponds to $0.56 \%$ of PTWI. This exposure estimate, which is not deemed to represent a health hazard, suggested a partial contribution to the serum OTA level in Japan.

Pork and poutly meats are regarded as the main animal sources of OTA intake by humans in Europe, and cereals are the main in temperate areas ${ }^{30}$. Our group already reported OTA residue in the plasma of farm animals ${ }^{16}$, suggesting possible residue of OTA in adible tissues. Furthemore, as shown in Table 3, soy-sauce, a well-known Asian traditional product, was positive for OTA, and the OTA producibility of fungi widely used for fermentation is pointed out. It means that the OTA residue in various kinds of fermented foodstuffs such as miso (bean-past) is highly possible in Asian countries. To solve the total exposure to OTA in the Japanese population, systematic survey of OTA in cereals, meats and fermented foodstuffs have to be programmed.

The presence of OTA in coffee beans and products ${ }^{33)}$, beer $^{12)}$, table wine and grape-juice ${ }^{34)}$ and ethinic foods ${ }^{35)}$ was already reported.

In this respect, the survey of OTA in cereals, foodstuffs, edible tissues of animals and traditional fermented products with sensitive, simple and reliable methods is expected to promote an understanding the total exposure level and risk of OTA, a carcinogenic and immunodepressive mycotoxin.

\section{References}

1) Steyn, P. S. : Mycotoxins, Production, Isolation, Separation and Purification, Betina, V. (Ed.), p. 183 (1984) Elsevier, Amsterdam. 
2) Krogh, P.: Mycotoxins. Purchase, I. F. H. (Ed.), p. 419 (1974) Elsevier Amsterdam.

3) Petrova-Bocharova, T., Chernozemsky, I. N. and Castegnaro, M. : Food Add. Contami., 5, 299 (1988).

4) Kanisawa, M. and Suzuki, S. : Gann, 69, 599 (1978).

5) Boorman, G. A. : NTT Technical Report on the Toxicology and Carcinogenesis Studies of Ochratoxin A in F344/N Rats (gavage studies). US Department of Health and Human Services, NIH, p. 1 (1989).

6) Pfohl-Leszkowicz, A., Grosse, A., Kane, M., Castegnaro, M., Creppy, E. E. and Dirheimer, G. : Mutation Res., 289, 265 (1993).

7) Thuvander, A., Breitholtz-Emanuelson, A. and Olson, M. : Food Chem. Toxicol., 33, 1005 (1995).

8) Environmental Health Criteria 105 : Selected Mycotoxins; Ochratoxins, Trichothecenes, Ergot. WHO, Geneva (1990).

9) Ueno, Y.: CRC Critical Rev. Toxicol., 14, 99 (1985).

10) Ueno, Y.: Toxicological Aspects of Food. Miller K. (Ed.) p. 139 (1987), Elsevier Appl. Sci., London and New York.

11) Størmer, F. C.: Handbook of Applied Mycology. Vol. 5, Mycotoxins in Ecological Systems. Bhatnagar, D., Lillehof, E. B. and Arota, D. K. (Eds). p. 403 (1992), Marcel Dekker Inc., New York.

12) Scott, P. M. and Kanhere, S. R. : Food Add. Contami., 12, 592. (1995).

13) van Egmont, H. P.: Food Add. Contami., 13, Suppl. 11 (1996).

14) Kawamura, O., Sato, S., Kajii, H., Nagayama, S., Ohtani, K., Chiba, J. and Ueno, Y.: Toxicon, 27, 887 (1989).

15) Kawamura, O., Sato, S., Nagura, N., Kishimoto, S., Ueno, I., Sato, S., Uda, T., Ito, Y. and Ueno, Y. Food Agric. Immunol., 2, 135 (1990).

16) Kawamura, O., Maki, S., Sato, S. and Ueno, Y. Human Ochratoxicosis and Pathologies. Creppy, E. E., Castegnaro, M. and Dirheimer, G. (Eds.), p. 159 (1993), INSERM/John Libbey Eurotext Ltd., Montrough and London.

17) Gareis, M., Martlbauer, E., Baue, J. and Gedek, B. : Z. Lebensm. Unters. Forsch., 186, 114 (1988).

18) Zimmerli B. and Dick R. : J. Chromatogr. B, 66, 85 (1995).

19) Hald, B. : Mycotoxins and Phycotoxins '88. Natori, S, Hashimoto, K. and Ueno, Y. (Eds.), p. 57 (1989) Elsevier, Amsterdam.

20) Furuya, M. and Kawamura, O.: Abst. 44 th Ann. Meet. Jpn. Assoc. Mycotoxicol. (Tokyo, January 15), p. 7 (1997).

21) Ueno, Y., Maki, S., Lin, J., Furuya, M., Sugiura, Y. and Kawamura, O., Food Chem. Toxicol., 36, 445 (1998).

22) Nakajima, M., Terada, H., Hisada, K., Tsubouchi, H., Yamamoto, K., Uda, Y., Ito, Y., Kawamura, O. and Ueno, Y. Food Agric. Immunol., 2, 189 (1990).

23) Nakajima, M., Tsubouchi, M., Miyabe, M. and Ueno, Y.: Food Agric. Immunol., 9, 77 (1997).

24) Breitholts-Emanuelsson, A., Olsen, M., Oskarsson A., Palminge I and Hult K. : J. Assoc. Off. Anal. Chem. Int., 76, 842 (1993).

25) Kuipper-Goodman, T., Ominski, K., Marquardt, R. R., Malcolm, S., McMullen, E., Lombaert, G. A. and Morton, T. : Human Ochatoxiosis and Pathologies. Creppy, E. E., Castegnaro, M. and Dirheimer, G. (Eds.), p. 167 (1993) INSERM/John Libbey Eurotext Ltd., Montrough and London

26) Ueno, Y., Kawamura, O., Sugiura, Y., Horikoshi, K., Nakajima, M., Yamamoto, K and Sato, S.: Mycotoxins, Endemic Nephropathy and Urinary Tract Tumours. p. 71 (1991) Castegnaro, M., Plestina, R., Dirheimer, G., Chernozimsky, I, and Bartsch, H. (Eds.), IARC, Lyon.

27) Ono, H., Kataoka, A., Koatsuku, I., Tanaka, T., Kawasugi, S., Kawazawa, M., Ueno, Y. and Manabe, M., Mycotoxins, 45, 47 (1995).

28) Varga, J., Kevei, E., Rinyu, E., Teren, J. and Kozakiewicz, Z. : Appl. Environ. Microbiol., 62, 446 (1996).

29) Kuipper-Goodman, T. and Scott, P. M.: Risk assessment of the mycotoxin ochratoxin A. Biomed. Environ. Sci., 2, 179 (1989).

30) WHO (World Health Organization). Evaluation of Certain Food Additives and Contaminants. Fortyfourth Report of the Joint FAO/WHO Expert Committee on Food Additives. (1996) WHO Technical Report Series No. 859, Geneve, WHO.

31) Tsubouchi, H., Terada, H., Yamamoto, K., Hisada, K. and Sakabe, Y.: Ochratoxin A found in commercial roast coffee. J Agric. Food Chem. 36, 540 (1988).

32) Studer-Rohr, I., Dietrich, D. R., Schlatter, J. and Schlatter, C.: The occurrence of ochratoxin A in coffee. 
Food Chem. Toxicol., 33, 341 (1995).

33) Stegen, G. v. d., Jörissen, U., Pittet, A., Saccon, M., Steiner, W., Vincenzi, M., Winkler, M., Zapp, J. and Schlatter, C. : Screening of Europian coffee final products for occurrence of ochratoxin A (OTA). Food Add. Contami., 14, 211 (1997).

34) Zimmerli, B. and Dick, R. : Food Add. Contami., 13, 655 (1996).

35) Patel S., Hazel G. M., Wintertion A. G. M. and Morthy E. Food Add. Contami., 13, 833 (1996). 